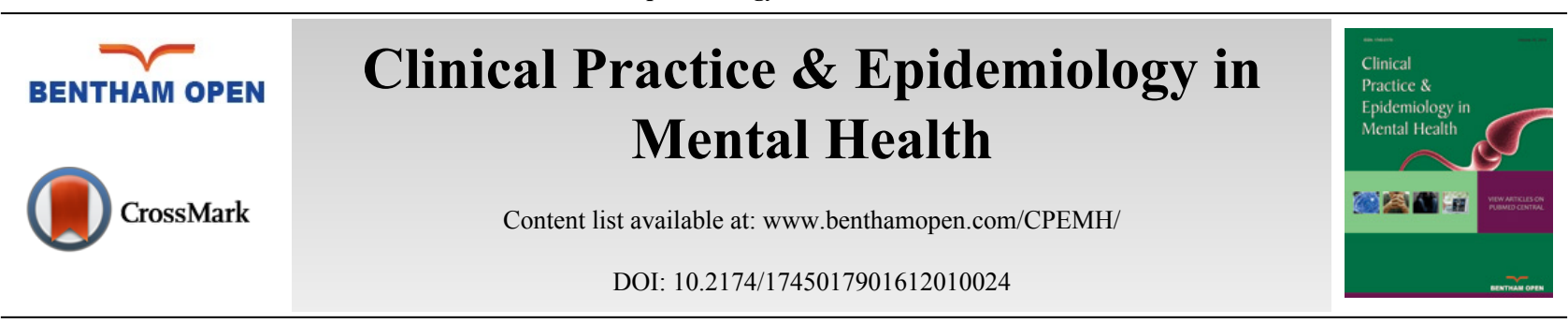

\title{
Dehydroepiandrosterone, Its Sulfate and Cognitive Functions
}

\author{
Karina Junqueira de Menezes ${ }^{1}$, Clayton Peixoto ${ }^{1}$, Antonio Egidio Nardi ${ }^{1}$, Mauro Giovanni Carta ${ }^{2}$, \\ Sérgio Machado ${ }^{1}$ and André Barciela Veras, ${ }^{3, *}$ \\ ${ }^{I}$ Laboratory of Panic and Respiration, Institute of Psychiatry, UFRJ (Federal University of Rio de Janeiro), Brazil \\ ${ }^{2}$ Department of Public Health, Clinical and Molecular Medicine, University of Cagliari, Cagliari, Italy \\ ${ }^{3}$ Dom Bosco Catholic University (UCDB), Laboratory of Panic and Respiration, Institute of Psychiatry, UFRJ, Brazil
}

Received: June 20, 2015

Revised: September 27, 2015

Accepted: December 2, 2015

\begin{abstract}
:
To present a review of cross-sectional and longitudinal studies that investigate the relationship between the hormones Dehydroepiandrosterone (DHEA) and Dehydroepiandrosterone sulfate (DHEA-S) and cognition. Methods: The cognition items included in this review were global cognitive function, memory, attention, executive function, intelligence, perception and visuospatial ability. A systematic review was proceeded using three databases: PubMed, ISI Web of Science, and PsycINFO. Results: Two thousand fifty five references about cognition and hormones were found; 772 duplicated references were excluded, resulting in 1.283 references to be evaluated. According to exclusion and inclusion criteria, 25 references were selected. A positive correlation between DHEA-S blood levels and global cognition was found in women and men. Other positive correlations between DHEA-S and working memory, attention and verbal fluency were found only in women. The DHEA effect on cognition is limited to one study conducted among young men with high-doses.
\end{abstract}

Keywords: Attention, Cognition, Dehydroepiandrosterone, Dehydroepiandrosterone Sulfate, Executive Function, Memory, Neuropsychology.

\section{INTRODUCTION}

Dehydroepiandrosterone (DHEA) and its sulfate (DHEA-S) are two active androgens mainly produced by the adrenal glands. DHEA is the main pro-hormone related to biosynthesis of testosterone and estrogen [1 - 4]. Studies have shown that these hormones are not synthesized just by the gonads and adrenal glands of men and women [1,2]. DHEA is also produced in brain regions, being recently considered a neurosteroid [3]. Although there is still debate on DHEA receptors in brain, these findings corroborate the evidence that DHEA is not just a pre-hormone from adrenals, but rather a hormone in its own right, and that it modulates a series of biological processes, with a remarkable tropism for the central nervous system [5].

DHEA-S is a protective anabolic hormone with an important role in maintaining and restoring the human organism. It is known for its antioxidant activity and ability to help in neuronal preservation. DHEA-S is originated in the zona reticularis area of the adrenal cortex in response to adrenocorticotropic hormone (ACTH). As DHEA, has a higher production between 25 and 35 years old and then gradually decrease over time [6,7]. Sex difference in DHEA-S levels remains unclear, while most studies reported higher levels in men than in women, others studies did not found differences [7 - 9].

The effects of DHEA and DHEA-S on cognitive functions have been targeted in all fields [10 - 12]. In a study that assessed the relationship between sex hormones and cognition, it was found that DHEA-S is positively associated with

* Address correspondence to this author at the Dom Bosco Catholic University (UCDB), Laboratory of Panic and Respiration, Institute of Psychiatry, UFRJ, Brazil; E-mail: barciela@ibest.com.br 
executive function and memory [13]. However, a literature review in the period of time between 1994 and 2013 observed that despite cross-cohort studies point to evidence of relationship between DHEA-S and cognition, RCTs and longitudinal studies were not able to consistently confirm these evidences [14]. Besides, the long term risk-effects remain unclear $[15,16]$.

Cognitive functions are organized by classes, similar to the operation of a computer. There are input, storage, processing and output classes [17 - 21] and each of these functional classes comprises of many discrete activities as perception, memory, attention, executive function and intellectual function [21 - 23]. One way to access the development and integrity of cognitive function is through neuropsychology, which is the study of the relationship between brain and behavior [23, 24]. Neuropsychological evaluation is a way of investigating different cognitive functions and their relations with brain function and its neurochemical factors, such as DHEA and DHEA-S.

Considering the recent speculation about the relationship between cognition and DHEA and DHEA-S, this paper aims to review the relationship between DHEA, DHEAS and cognitive functions.

\section{METHODS}

A systematic search of the literature was proceeded in PubMed, ISI Web of Knowledge and PsycINFO, using the terms: Dehydroepiandrosterone, Dehydroepiandrosterone sulfate, DHEA, DHEAS, cognition, cognitive function, memory, attention, executive function, intelligence, perception, visuospatial ability. All combinations between the first four terms for the specific hormones of this review were crossed with each specified mental function. The last search was proceeded in October 2015 and no time restriction was used. Two thousand and fifty three references were found (PubMed, 1217; The study selection process obeyed the following steps: Database search; exclusion of repeated references; summary analysis; exclusion of articles deemed ineligible after reading the summaries; full analysis of potentially eligible articles; exclusion of articles considered ineligible after complete reading; and the final selection of studies considered suitable to compose this review (Fig. 1).

References analyzed were included if they met the inclusion criteria: 1) report at least one cognitive function assessed by neuropsychological measures and 2) report clinical or community-based studies with populations that had DHEA or DHEA-S levels assessed. The, exclusion criteria were: 1) review papers; 2) studies that included population with genetic syndromes (such as Down syndrome, Turner's disorder, and Klinefelter's), severe cognitive impairment (such as schizophrenia, dementia, and epilepsy) and endocrine diseases (such as polycystic ovary syndrome, androgen insensitivity syndrome and others); 3) studies with animals. After abstract analysis, 25 references were selected for this review (Table 1).

Methodology was based on the Preferred Reporting Items for Systematic reviews and Meta-analyses (PRISMA), which addresses conceptual and practical advances in systematic reviews [25].

\section{RESULTS}

\subsection{Cognitive Functions Assessed}

Despite growing knowledge about the role of DHEA and DHEA-S in the central nervous system, the majority of the research has focused on manifestations of sexual disorders, mood and aging [16 - 20] rather than the assessment of the relationship between these hormones and cognitive functions $[18,19]$.

In this review, the most evaluated topics were global cognition ( $\mathrm{n}=13$ articles) and memory ( $\mathrm{n}=11)$, followed by attention $(n=4)$, executive function $(n=3)$, intelligence $(n=2)$, perception $(n=1)$ and visuospatial ability $(n=1)$. Several studies evaluated more than one cognitive function.

\subsubsection{Global Cognition}

Cognitive functions constitute a set of the basic elements of cognition such as: perception, learning, memory, attention, vigilance and reasoning among others $[21,26]$. Through cognition humans are able to process all information stored in brain [26]. Fourteen articles addressed the relationships between DHEA, DHEA-S and global cognition. Concerning the endogenous levels of DHEA and/or DHEA-S, 12 articles were found. 


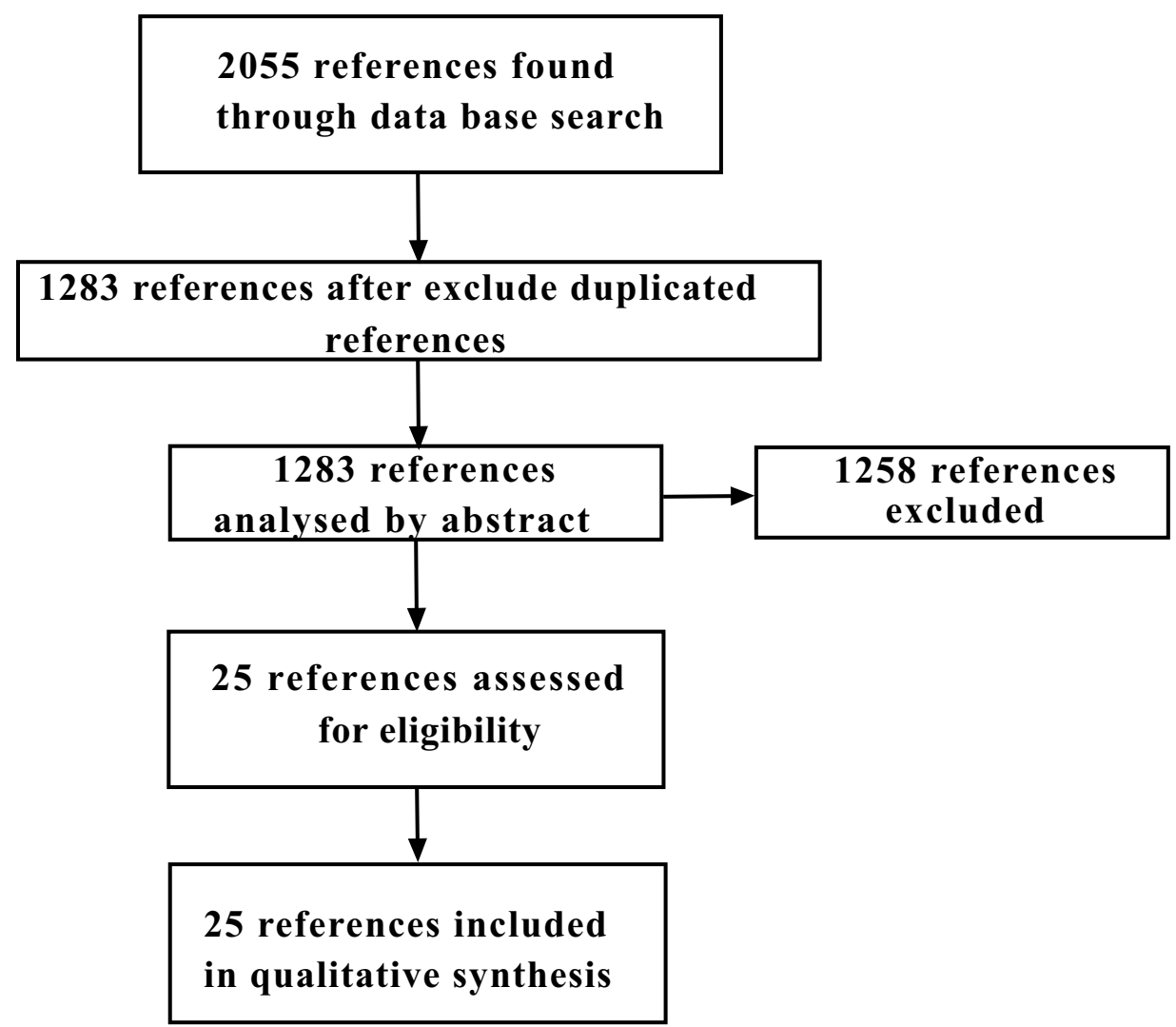

Fig. (1). Flowchart of the different phases of the systematic review.

\subsubsection{Correlations in Both Genders Samples}

In a cross-sectional evaluation of healthy elderly subjects $(n=313$; women, mean age, $77.3 \pm 6.4$ years; men, mean age, 76.7 \pm 5.4 years), the Mini-Mental State Examination (MMSE) was presented and blood samples were collected. The results showed that DHEA had a negative correlation with cognitive function in women $(\mathrm{b}=-.79, p=.03)[5]$.

Two articles from the same research group using the same sample and battery of tests showed: In the first study, 967 elderly Taiwanese were evaluated and blood and urine samples were collected. DHEA-S was positively associated with cognitive function in women [27]. In the second study, these authors compared the results of previous evaluations from the same sample in 836 elderly patients. This time, a positive correlation was found between DHEA-S and cognitive function in $86 \%$ of the male sample $(\mathrm{r}=-0.0016, p<0.001)$ [28]. Corroborating this last finding, in a study among older elderly Japanese adults $(\mathrm{n}=208)$ assessed by the Hasegawa Dementia Scale - Revised, blood levels of DHEA-S were associated with better cognitive function in men [29].

Another study, published into two papers, evaluated 86 elderly people using an extended neuropsychological battery. Both transversal and longitudinal assessments did not show any correlations between hormones and cognition $[30,31]$. Similarly, another study using elderly subjects $(n=145)$ failed to find any correlation between hormonal levels and MMSE scores [32].

\subsubsection{Correlations in Male Samples}

A cross-sectional study of elderly African men $(n=124)$, using the multiple linear regression model, found that higher levels of DHEA-S, measured from blood samples, were associated with higher scores of MMSE ( $b=.098$; $p=.008$ ) [9]. The other study evaluated 883 men for a period of 31 years period. DHEA-S blood levels were measured, and neuropsychological assessments were performed every two years. The comparison between the first and the last assessments found no statistically significant associations between DHEA-S levels and cognition [10]. 


\subsubsection{Correlations in Female Samples}

A cross-sectional study of DHEA-S using MMSE compared healthy elderly women $(n=103)$ with a control group of healthy young women $(n=25)$. Significantly $(p<0.01)$ lower concentrations of DHEA-S were observed in women with lower MMSE scores compared to those with higher MMSE scores [33]. Another study aimed to evaluate the association between the decline of blood levels of DHEA-S and cognitive functions over the years. Elderly women ( $\mathrm{n}=394)$ were assessed using the MMSE and neuropsychological tests at baseline and 4-6 years later. No associations were found between the cognitive performance and DHEA-S [11]. Similarly, a study assessing transversal and longitudinal global cognition in 218 Australian post-menopausal women through a composite derived from standardized scores of 17 individual test scores, found no significant relations between levels of DHEA-S and cognitive function [34].

\subsubsection{Intervention Studies}

In the first paper, MMSE was used for evaluation and $1 \mathrm{mg}$ of dexamethasone was administered for 1 year and 9 months to elderly men and women $(n=189)$. DHEA-S blood levels were measured before and after this medication and no statistically significant relationships were found between the hormone levels and cognitive impairment [33]. The longitudinal study, in which only postmenopausal women $(\mathrm{n}=20)$ received DHEA supplementation $(25 \mathrm{mg})$ for 6 months, showed different results. A battery of tests was administered at the beginning (T1) and at the end (T2) of the treatment period. DHEA, DHEA-S and cortisol levels from blood samples were also measured. DHEA-S and the cortisol/DHEA ratios appeared to be negatively correlated with cognition before and after supplementation [36].

Although some studies have shown a positive correlation between DHEA and cognition, others have shown negative correlations, indicating that these relations are not yet clear. Two cross-sectional studies revealed a positive correlation between the DHEA-S levels and global cognition in women, whereby the first study used a battery of neuropsychological tests [27] and the second study used MMSE [33]. The cross-sectional study using MMSE showed a negative correlation between DHEA and cognition in women [5]. In the male population, 3 studies showed a positive correlation with DHEA-S among older men [9, 28, 29]. Seven studies failed to observe any connection between hormonal levels and cognition [10, 11, 30 - 32, 34, 35] and one identified negative correlations in women [36].

\subsubsection{Memory}

Memory is a function that gives meaning to time, maintains one's identity and ensures learning [23]. The complex process of memory requires a number of successive stages and it cannot be construed as a solitary system. Memory can be divided into working memory, declarative memory, procedural memory, short-term memory, long-term memory, and others [37, 38]. In this sample, 11 articles included have addressed memory. Four articles focusing on the endogenous levels of DHEA or DHEA-S and 7 articles are on DHEA supplementation.

\subsubsection{Correlations in Both Genders Samples}

The first cross-sectional study, using a sample of healthy elderly adults $(n=313)$ assessed by memory components of the MMSE, showed that episodic declarative memory was negatively correlated with DHEA blood levels in women [5]. Another cross-sectional study, only with women ( $n=295$ between the ages of 21 and 77 years), suggested a positive relationship between DHEA-S levels and working memory [39].

\subsubsection{Correlations in Male Samples}

One study was performed in 25 elderly men to assess long-term verbal memory. No correlation was found with DHEA-S blood levels in men [40]. Similarly, a survey of 981 elderly men showed no correlation between DHEA-S or DHEA blood levels and working memory [12].

\subsubsection{Intervention Studies}

Three of these studies were conducted using only male subjects. The first study evaluated 46 men. They received 50 mg DHEA daily for 13 weeks followed by placebo for 13 weeks, or the reverse. Salivary cortisol and DHEA levels were measured and cognition was assessed using Word List Memory and Object Location Memory. No significant effects of DHEA were observed in any of the trial outcomes, providing no support for benefits of DHEA supplementation for episodic declarative memory, despite the significant increase of DHEA levels after treatment [41]. Similarly, 17 elderly men on placebo or DHEA (50 mg/day) for 2 weeks (double blind) did not enhance their declarative and visual memory [42]. However, the last study showed that DHEA supplementation can influence on 
memory aspects. The sample composed of young men $(n=24)$ had the episodic memory assessed after daily DHEA supplementation (300 mg for 7 days). Significant effects when compared to the placebo group were found [43].

Studies comprising only of women showed different results. The first study, conducted among postmenopausal women $(n=6)$, demonstrated that DHEA supplementation influenced memory. This sample was treated with 50 mg of DHEA daily for 4 weeks and showed negative effects of androgens on recognition memory. Recognition memory was observed to be negatively correlated to the level of ANDRO factor [44]. The second longitudinal study, using a daily dose of $50 \mathrm{mg}$ of DHEA for 4 weeks, did not lead to short-term memory improvements in postmenopausal women $(\mathrm{n}=48)[45]$.

Two other studies comprised of men and women. Divided into control and treatment groups, 111 men and 118 women (mean age 68.7 \pm 7.9) received $50 \mathrm{mg}$ of DHEA or placebo for one year. These groups were assessed using the Word List Memory and Word List Recall tests. No difference was found between groups in terms of changes in declarative memory [46]. Another study with 40 elderly men and women also found no effect on memory after DHEA supplementation [47].

Results regarding memory demonstrated a correlation between working memory and DHEA-S in women in just one cross-sectional study [39]. One longitudinal study, which focused on DHEA supplementation, demonstrated a negative correlation between DHEA and recognition memory in women [44], whereas other studies failed to demonstrate the effects of hormonal supplementation on working memory and episodic declarative memory [45 - 47]. In men, the majority of studies showed no relationship between DHEA or DHEA-S and all types of memory functions [5, 12, 40 $42,46,47]$. The only study that demonstrated a correlation between DHEA and memory was a longitudinal study, which used a higher DHEA dose supplementation (300 mg for 7 days) in young males [43]. All other studies that failed to demonstrate effects were conducted with a $50 \mathrm{mg}$ daily dose [41, 42, $44-47]$.

\subsubsection{Attention}

Among the articles included in this review, 4 articles evaluated attention. Attention is a cognitive function defined as the ability to target and select information, inside and outside of the body, to maintain vigilance and organize behavior and mental processes [37, 38]. It is also defined as the direction of consciousness or a state of mental concentration about a specific object [49]. Attention is considered a multifaceted system and some authors subdivide it in focused attention; selective attention; response selection and executive control; and sustained attention [22, 38, 49].

\subsubsection{Correlations in Female Samples}

One cross-sectional study that assessed attention in women ( $\mathrm{n}=295$; age range, 21-77 years) found that DHEA-S blood levels are positively correlated with attention [39]. Another cross-sectional study conducted in elderly men $(\mathrm{n}=981)$ showed no correlations with DHEA or DHEA-S [12].

\subsubsection{Intervention Studies}

A longitudinal study of postmenopausal women $(n=6)$ identified a negative relationship between the variable ANDROfactor and attention [44]. The longitudinal study conducted on 40 elderly subjects from both genders found no significant effect of $50 \mathrm{mg}$ DHEA for two weeks on attention [47].

Again, a positive correlation was found only in a cross-sectional study with women [39] ,but not in the crosssectional study with men [12]. Longitudinal studies with DHEA replacement showed no effects on either men and women [47] or even a negative relationship between androgens and attention [44].

\subsubsection{Executive Function}

Executive function is a set of skills that allows individuals to perform and control operations and to regulate information in the brain. Executive function can be divided into working memory, planning, problem solving, decision making, inhibitory control, fluency, cognitive flexibility, categorization, and others [23, 38]. The assessment of executive function was performed in 3 studies; one study reporting endogenous levels and 2 studies reporting DHEA supplementation.

\subsubsection{Correlations in Female Samples}

The cross-sectional study of a sample of 295 women (age range, 21-77 years) used the Controlled Oral Word 
Association Test (FAS) to assess verbal fluency, which is an executive function. Higher DHEA-S blood levels corresponded with higher FAS scores, indicating a positive correlation between verbal fluency and DHEA-S [39].

\subsubsection{Intervention Studies}

Two longitudinal studies [46, 47] with mixed populations did not find any relationship between DHEA supplementation and an improvement of the executive functions. In the first study, 110 men and 115 women (mean age, 68.7 \pm 7.9 years) were divided into treatment and placebo groups. The treatment group received $50 \mathrm{mg}$ of DHEA for one year [46]. In the second study, 25 elderly men and 15 elderly women received two weeks of $50 \mathrm{mg}$ of DHEA. Analyses showed no significant correlations [47].

The types of executive function studied in the articles were verbal fluency, categorization and cognitive flexibility. As observed in other cognitive functions, the cross-sectional study showed a correlation between DHEA-S and verbal fluency in women [39], whereas the two longitudinal studies, showed no improvement on categorization or cognitive flexibility with DHEA administration [46, 47].

\subsubsection{Intelligence}

Intelligence is a broad and widely used concept, but so far there is no definitive concept about it. However, we can define it as the ability to identify and solve new problems and find the best possible solution, it is the outcome of the individual's intellectual skills [49], but not includes only skills and abilities, and also includes how the brain works to process the information it receives [38]. Two studies investigated the relationship between DHEA, DHEA-S and intelligence, measuring the endogenous levels of hormones [40, 48].

The first study was conducted in 25 elderly men and evaluated crystallized intelligence, which is not sensitive to aging, and fluid intelligence, which is sensitive to aging. The results showed that DHEA-S blood levels were neither correlated with crystallized intelligence nor with fluid intelligence [40]. The other study was conducted in children ( $n=60$ boys and 69 girls; mean age $=5$ years 11 months) using the Kaufman Brief Intelligence Test and a negative correlation was found $(\mathrm{r}=-0.121, P<0.05$. $)$ [42].

\subsubsection{Perception and Visuospatial Ability}

Perception is a complex and active process in which one examines and formulates a hypothesis about the present [37]. The perception can also be described as the awareness of sensory stimuli, external objects or facts of different complexity degrees [49]. Visuospatial ability is a broad construct and involves the ability to produce, record, recall and work with images and visual sensations via global processing [50]. Some of the specific skills involved in visuospatial ability are: visualization, spatial relationships, closing speed, closing flexibility, visual memory and spatial rummage [51].

One study was found for each of these cognitive functions. For the first function, a longitudinal study conducted among postmenopausal women $(n=6)$ assessed the relationship between visual perception and DHEA after treatment with $50 \mathrm{mg}$ of DHEA daily for 4 weeks. The results of the Perceptual Identification Test showed that androgen hormones were negatively correlated with perception $(\mathrm{r}=-.28)$ [44]. The second study, a cross-sectional one, explored visuospatial ability and the endogenous levels of DHEA and DHEA-S. It was conducted in older adults ( $\mathrm{n}=981$; mean age, 62.66 years) using the Relation Figural Test. Results showed no relationship between visuospatial ability and blood levels of DHEA-S or DHEA [12]

Table 1. Summary of the studies included in this review.

\begin{tabular}{|c|c|c|c|c|c|c|c|c|c|c|c|c|c|c|c|}
\hline Autors (Year) (Type) & $\mathrm{n}$ & $\mathbf{M} / \mathbf{F}$ & Age & \begin{tabular}{|c|} 
Body \\
fluid \\
measured
\end{tabular} & Memory & Attetion & \begin{tabular}{|l|} 
Executive \\
Functions
\end{tabular} & \begin{tabular}{|c|} 
Visuospatial \\
abilities and \\
psychomotor
\end{tabular} & Perception & Inteligence & $\left|\begin{array}{c}\text { Global } \\
\text { Cognition }\end{array}\right|$ & $\begin{array}{l}\text { Neuropsychocological Assement } \\
\text { Instruments }\end{array}$ & Result & $\begin{array}{c}\text { Methodological } \\
\text { aspects }\end{array}$ & Ref \\
\hline $\begin{array}{l}\text { Chua et al (2014)34 } \\
\text { (longitudinal study) }\end{array}$ & $\begin{array}{l}218 \\
\text { PMW }\end{array}$ & $0 / 218$ & 59,7 & $\begin{array}{c}\text { Blood } \\
\text { samples }\end{array}$ & & & & & & & $\mathrm{X}$ & $\begin{array}{l}\text { A comprehensive battery of } 13 \text {-item } \\
\text { neuropsychological tests. }\end{array}$ & \begin{tabular}{|c|} 
The analyses \\
demonstrated no \\
significant relation \\
between DHEAS \\
level and cognitive \\
function in midlife, \\
postmenopausal \\
women.
\end{tabular} & \begin{tabular}{|c|}
- Adults and \\
Elderly \\
- Set of tests \\
- Female \\
population
\end{tabular} & [34] \\
\hline
\end{tabular}




\begin{tabular}{|c|c|c|c|c|c|c|c|c|c|c|c|c|c|c|c|}
\hline Autors (Year) (Type) & $\mathbf{n}$ & $\mathbf{M} / \mathbf{F}$ & Age & $\begin{array}{c}\text { Body } \\
\text { fluid } \\
\text { measured }\end{array}$ & Memory & Attetion & \begin{tabular}{|l|} 
Executive \\
Functions
\end{tabular} & $\begin{array}{c}\text { Visuospatial } \\
\text { abilities and } \\
\text { psychomotor }\end{array}$ & Perception & Inteligence & $\mid \begin{array}{c}\text { Global } \\
\text { Cognition }\end{array}$ & $\begin{array}{l}\text { Neuropsychocological Assement } \\
\text { Instruments }\end{array}$ & Result & $\begin{array}{c}\text { Methodological } \\
\text { aspects }\end{array}$ & Ref \\
\hline $\begin{array}{c}\text { Merritt et al (2012)38 } \\
\text { (longitudinal study) }\end{array}$ & $\begin{array}{c}48 \\
\text { PMW }\end{array}$ & $0 / 48$ & $\begin{array}{c}63,5+/- \\
6,85\end{array}$ & ${ }^{*}$ & $\mathrm{x}$ & & & & & & & \begin{tabular}{|c|} 
- Mini Mental State \\
Examination (MMSE) \\
- Digit Span Forward test (Wechsler \\
Memory Scale-Third Edition) \\
• Digit Span Backward test \\
(Wechsler Memory Scale-Third \\
Edition) \\
- Verbal Span Performance \\
- Modified Spenberg Paradigm \\
\end{tabular} & \begin{tabular}{|c|} 
Despite this \\
substantial change \\
in the hormonal \\
milieu, DHEA \\
administration \\
produced no \\
beneficial effects \\
on cognitive \\
performance in the \\
digit span, verbal \\
span, or modified \\
Sternberg paradigm \\
tasks. \\
\end{tabular} & \begin{tabular}{|}
$\cdot$ Elderly \\
Body fluid \\
measured \\
wasn't cited \\
$\cdot$ Set of \\
instruments \\
- Female \\
population \\
\end{tabular} & [38] \\
\hline $\begin{array}{l}\text { Fukai } \text { et al (2009)23 } \\
\text { (cross-sectional study) }\end{array}$ & $\begin{array}{l}208 \\
\text { EFD }\end{array}$ & $\begin{array}{l}108 / \\
100\end{array}$ & $\begin{array}{c}70-95 \\
\text { Years (M) } \\
70-93 \\
\text { Years }(\mathrm{W})\end{array}$ & $\begin{array}{c}\text { Blood } \\
\text { samples }\end{array}$ & & & & & & & $\mathrm{x}$ & $\begin{array}{c}\text { - Hasegawa Dementia Scale - } \\
\text { Revised }\end{array}$ & \begin{tabular}{|c|} 
Only in men \\
DHEA(-S) was \\
associated with \\
cognitive function.
\end{tabular} & $\begin{array}{c}\cdot \text { Elderly } \\
\cdot \text { Scale } \\
\cdot \text { Male and } \\
\text { Female } \\
\text { population }\end{array}$ & [23] \\
\hline $\begin{array}{c}\text { Alfaro et al (2008)5 } \\
\text { (cross-sectional study) }\end{array}$ & $313 \mathrm{E}$ & $\begin{array}{l}153 / \\
160\end{array}$ & $\begin{array}{r}76,7+/-5,4 \\
\text { (M) } 75,3 \\
+/-6,4(\mathrm{~W})\end{array} \mid$ & $\begin{array}{c}\text { Blood } \\
\text { samples }\end{array}$ & $\mathrm{x}$ & & & & & & $\mathrm{x}$ & $\begin{array}{l}\text { • Mini Mental State } \\
\text { Examination (MMSE) }\end{array}$ & $\begin{array}{c}\text { In women, adrenal } \\
\text { steroids showed a } \\
\text { negative correlation } \\
\text { with global } \\
\text { cognition. For } \\
\text { memory function, } \\
\text { DHEA also } \\
\text { correlated } \\
\text { negatively in } \\
\text { women. No } \\
\text { relationships with } \\
\text { cognition were } \\
\text { observed in men for } \\
\text { any of the steroids. } \\
\end{array}$ & \begin{tabular}{|c|} 
- Elderly \\
- Screaming \\
test \\
- Male and \\
Female \\
population \\
\\
\end{tabular} & [5] \\
\hline $\begin{array}{l}\text { Kritz-Silverstein et al } \\
\text { (2008)39 (longitudinal } \\
\text { survey) }\end{array}$ & $\begin{array}{l}112 \mathrm{DT} \\
113 \mathrm{P}\end{array}$ & $\begin{array}{l}110 / \\
115\end{array}$ & $68,7+/-7,9 \mid$ & $\begin{array}{c}\text { Blood } \\
\text { samples }\end{array}$ & $\mathrm{x}$ & & $\mathrm{x}$ & & & & & $\begin{array}{l}\text { - Category Fluency } \\
\text { - Word List Memory } \\
\text { - Word List Recall }\end{array}$ & \begin{tabular}{|c|} 
There were no \\
differences between \\
the DHEA and \\
placebo groups in \\
change over time in \\
cognitive function \\
(P>.10). DHEA \\
supplementation \\
has no benefit on \\
cognitive \\
performance in \\
healthy older \\
adults, and it should \\
not be \\
recommended for \\
that purpose in the \\
general population. \\
\end{tabular} & \begin{tabular}{|} 
- Elderly \\
- Set of tests \\
- Male and \\
Female \\
population \\
\\
\end{tabular} & [39] \\
\hline $\begin{array}{c}\text { Davis et al (2008)32 } \\
\text { (cross-sectional study) }\end{array}$ & $295 \mathrm{~W}$ & $0 / 295$ & $55+/-12,8 \mid$ & $\begin{array}{c}\text { Blood } \\
\text { samples }\end{array}$ & $\mathrm{x}$ & $\mathrm{x}$ & $\mathrm{x}$ & & & & & $\begin{array}{c}\text { - Controlled Oral Word Association } \\
\text { Test score } \\
\text { - Digit Span Forward test (Wechsler } \\
\text { Memory Scale-Third Edition) } \\
\text { - Digit Span Backward test } \\
\text { (Wechsler Memory Scale-Third } \\
\text { Edition) } \\
\text { - California Verbal Learning Test } \\
\text { Immediate } \\
\text { - Wechsler Memory Scale-Third } \\
\text { Edition } \\
\text { - Stroop Color-Naming Interference } \\
\text { Test } \\
\text { - Trail Making Test B (TMTB) } \\
\end{array}$ & \begin{tabular}{|c|} 
DHEAS term made \\
a significant \\
independent \\
Positive \\
contribution to the \\
Controlled Oral \\
Word Association \\
Test score, a \\
measure of \\
executive function. \\
In addition, women \\
with a DHEAS \\
level in the highest \\
tertile who also had \\
more than 12 yr of \\
education \\
performed better on \\
both Digit Span \\
Forward and Digit \\
Span Backward \\
tests, which are \\
tests of simple \\
concentration and \\
working memory, \\
respectively. \\
\end{tabular} & \begin{tabular}{|c|}
- Adults and \\
Elderly \\
- Set of tests \\
- Female \\
population \\
\\
\\
\end{tabular} & [32] \\
\hline $\begin{array}{c}\text { Kędziora-Kornatowska } \\
\text { et al (2007)27 (cross- } \\
\text { sectional study) }\end{array}$ & $\begin{array}{l}103 \\
\text { EHW } \\
25 \mathrm{C}\end{array}$ & $0 / 128$ & $|70,7+/-7,3|$ & $\begin{array}{c}\text { Blood } \\
\text { samples }\end{array}$ & & & & & & & $\mathrm{x}$ & $\begin{array}{l}\text { - Mini-Mental State Examination } \\
\text { (MMSE) }\end{array}$ & \begin{tabular}{|c|} 
Statistically \\
significantly lower \\
DHEA-S \\
concentration was \\
observed in patients \\
with benign \\
disorders of \\
cognitive functions \\
and depression \\
compared with \\
patients with \\
correct MMSE \\
\end{tabular} & $\begin{array}{c}\text { - Elderly } \\
\text { - Screaming } \\
\text { test } \\
\text { - Female } \\
\text { population } \\
\\
\end{array}$ & [27] \\
\hline $\begin{array}{c}\text { Haren et al (2007)6 } \\
\text { (cross-sectional study) }\end{array}$ & $\begin{array}{c}124 \\
\text { EHM }\end{array}$ & $124 / 0$ & $56,1+/-4,4 \mid$ & $\begin{array}{c}\text { Blood } \\
\text { samples }\end{array}$ & & & & & & & $\mathrm{x}$ & $\begin{array}{l}\text { • Mini-Mental State Examination } \\
\text { (MMSE) } \\
\text { • Trail-making test (TMT) }\end{array}$ & \begin{tabular}{|c|} 
Higher DHEAS \\
levels were \\
associated with \\
higher mini-mental \\
state examination \\
(MMSE) score (b \\
$=0.098, \mathrm{p}=0.008)$.
\end{tabular} & \begin{tabular}{|c|} 
- Adults \\
- Screaming \\
test plus \\
gold pattern \\
test \\
- Male \\
population \\
\end{tabular} & [6] \\
\hline $\begin{array}{c}\text { Goldman e Glei } \\
\text { (2007)22 (longitudinal } \\
\text { survey) }\end{array}$ & $836 \mathrm{E}$ & * & $\begin{array}{c}54 \text { and } \\
\text { older }\end{array}$ & $\begin{array}{c}\text { Blood } \\
\text { samples }\end{array}$ & & & & & & & $\mathrm{x}$ & $\begin{array}{c}\text { Items from: } \\
\text { - Short Portable Mental Status } \\
\text { Questionnaire } \\
\text { - Rey Auditory Verbal Learning } \\
\text { Test } \\
\text { • Digits Backward test }\end{array}$ & \begin{tabular}{|c|} 
In most men low \\
levels of DHEAS \\
are associated with \\
poor cognitive \\
function. There are \\
no significant \\
associations among \\
women.
\end{tabular} & $\begin{array}{c}- \text { Adults and } \\
\text { Elderly } \\
\text { - Set of tests } \\
\text { - Male and } \\
\text { Female }\end{array}$ & [22] \\
\hline
\end{tabular}




\begin{tabular}{|c|c|c|c|c|c|c|c|c|c|c|c|c|c|c|c|}
\hline Autors (Year) (Type) & $\mathbf{n}$ & $\mathbf{M} / \mathbf{F}$ & Age & \begin{tabular}{|c|}
$\begin{array}{c}\text { Body } \\
\text { fluid } \\
\text { measured }\end{array}$ \\
\end{tabular} & Memory & Attetion & \begin{tabular}{|l|} 
Executive \\
Functions
\end{tabular} & \begin{tabular}{|c|}
$\begin{array}{c}\text { Visuospatial } \\
\text { abilities and } \\
\text { psychomotor }\end{array}$ \\
P
\end{tabular} & Perception & Inteligence & $\mid \begin{array}{c}\text { Global } \\
\text { Cognition }\end{array}$ & $\begin{array}{l}\text { Neuropsychocological Assement } \\
\text { Instruments }\end{array}$ & Result & $\begin{array}{c}\text { Methodological } \\
\text { aspects }\end{array}$ & Ref \\
\hline $\begin{array}{l}\text { Arai et al (2006)26 } \\
\text { (cross-sectional) }\end{array}$ & $145 \mathrm{E}$ & $58 / 87$ & $\begin{array}{c}75,6+/- \\
0.56\end{array}$ & \begin{tabular}{|c|} 
Blood \\
samples
\end{tabular} & & & & & & & $\mathrm{x}$ & $\begin{array}{l}\text { - Mini-Mental State Examination } \\
\text { (MMSE) }\end{array}$ & $\begin{array}{c}\text { The levels of } \\
\text { DHEA e DHEA-S } \\
\text { were not associated } \\
\text { with MMSE. }\end{array}$ & \begin{tabular}{|c} 
- Elderly \\
- Screaming \\
test \\
- Male and \\
Female \\
population
\end{tabular} & [26] \\
\hline $\begin{array}{c}\text { Parsons et al (2006)29 } \\
\text { (longitudinal survey) }\end{array}$ & $\begin{array}{l}11 \mathrm{DT} \\
9 \mathrm{P}\end{array}$ & $\begin{array}{l}0 / 20 \\
\text { PMW }\end{array}$ & $\begin{array}{l}46-66 \\
\text { years }\end{array}$ & $\begin{array}{c}\text { Blood } \\
\text { samples }\end{array}$ & & & & & & & $\mathrm{x}$ & $\begin{array}{c}\text { - California Verbal Learning } \\
\text { Test (CVLT) } \\
\text { • Wechsler Adult Intelligence } \\
\text { Scale-Revised (WAIS-R) } \\
\text { • Digit Span Forward } \\
\text { - Digit Span Backward } \\
\text { - Trail Making Test A and B } \\
\text { • Golden } \\
\text { Stroop Test } \\
\text { - Token Test } \\
\text { - Category Fluency } \\
\text { - Boston Naming Test } \\
\text { • Test of } \\
\text { Nonverbal Intelligence-2 (TONI-2) } \\
\text { • Judgment of Line Orientation }\end{array}$ & \begin{tabular}{|c|} 
An increase in \\
negative \\
associations \\
between DHEA(S) \\
levels and cognition \\
was found at \\
completion. \\
Increased cortisol \\
does not explain the \\
cognitive deficits \\
associated with \\
DHEA, suggesting \\
a direct negative \\
effect of exogenous \\
DHEA on \\
cognition.
\end{tabular} & \begin{tabular}{|c|}
- Adults and \\
Elderly \\
- Set of tests \\
- Female \\
population \\
\\
\end{tabular} & [29] \\
\hline $\begin{array}{l}\text { Alhaj et al (2006)36 } \\
\text { (longitudinal survey) }\end{array}$ & $24 \mathrm{YM}$ & $24 / 0$ & $23,6+1-5,1$ & $\begin{array}{c}\text { Saliva } \\
\text { samples }\end{array}$ & $\mathrm{x}$ & & & & & & & - Visual analogue scales (VASs) & \begin{tabular}{|c|} 
DHEA \\
administration led \\
to a reduction in \\
evening cortisol \\
concentrations and \\
improved VAS \\
mood and memory. \\
Recollection \\
accuracy in the \\
episodic memory \\
test was \\
significantly \\
improved following \\
DHEA \\
administration.
\end{tabular} & $\begin{array}{l}\text { •Young } \\
\text { - Scale } \\
\text { - Male } \\
\text { population } \\
\\
\end{array}$ & [36] \\
\hline $\begin{array}{l}\text { Azurmendi et al } \\
\text { (2005)41 (cross- } \\
\text { sectional) }\end{array}$ & $129 \mathrm{C}$ & $60 / 69$ & $\begin{array}{c}5 \text { years } 11 \\
\text { months } \\
\text { mean age }\end{array}$ & $\begin{array}{c}\text { Saliva } \\
\text { samples }\end{array}$ & & & & & & $\mathrm{x}$ & & $\begin{array}{c}\text { - Kaufman Brief Intelligence Test } \\
\text { (K-BIT) }\end{array}$ & \begin{tabular}{|c|} 
DHEA was not a \\
good predictor for \\
fluid intelligence \\
and crystallized \\
intelligence in both \\
genders.
\end{tabular} & \begin{tabular}{|c|} 
- Children \\
- Set of tests \\
- Male and \\
Female \\
population
\end{tabular} & [41] \\
\hline $\begin{array}{l}\text { Fonda et al (2005)9 } \\
\text { (cross-sectional) }\end{array}$ & $\begin{array}{l}981 \\
\text { EHM }\end{array}$ & $981 / 0$ & 62,66 years & $\begin{array}{c}\text { Blood } \\
\text { samples }\end{array}$ & $\mathrm{x}$ & $\mathrm{x}$ & & $\mathrm{x}$ & & & & $\begin{array}{c}\text { - Backward Digit Span test } \\
\text { - Digit Symbol Substitution test } \\
\text { - Figural Relations test }\end{array}$ & $\begin{array}{c}\text { The direct effects of } \\
\text { hormones on } \\
\text { cognition are not } \\
\text { significant when } \\
\text { salient factors } \\
\text { (educational } \\
\text { attainment, health } \\
\text { conditions and } \\
\text { behaviors, body } \\
\text { mass index, and } \\
\text { depression) are } \\
\text { considered. } \\
\end{array}$ & \begin{tabular}{|c|}
$\cdot$ Elderly \\
- Set of tests \\
- Male \\
population \\
\\
\end{tabular} & [9] \\
\hline $\begin{array}{l}\text { Glei et al (2004)21 } \\
\text { (cross-sectional) }\end{array}$ & $967 \mathrm{E}$ & $*$ & $\begin{array}{c}54 \text { and } \\
\text { older }\end{array}$ & $\begin{array}{c}\text { Blood and } \\
\text { urine } \\
\text { samples }\end{array}$ & & & & & & & $\mathrm{x}$ & $\begin{array}{c}\cdot 12 \text { items from the } \\
\text { modified Short Portable Mental Status } \\
\text { Questionnaire } \\
\text { - Rey Auditory Verbal Learning } \\
\text { Test } \\
\text { - Digits } \\
\text { Backward test. }\end{array}$ & $\begin{array}{c}\text { Results reveal that } \\
\text { higher levels of } \\
\text { DHEAS are } \\
\text { associated with } \\
\text { better cognitive } \\
\text { function (among } \\
\text { women but not } \\
\text { men) }\end{array}$ & \begin{tabular}{|c|} 
- Adults and \\
Elderly \\
- Set of tests \\
- Male and \\
female \\
population
\end{tabular} & [21] \\
\hline $\begin{array}{c}\text { Hirshman et al } \\
\text { (2004)37 (longitudinal } \\
\text { study) }\end{array}$ & $6 \mathrm{PMW}$ & $0 / 6$ & $\begin{array}{l}53-68 \\
\text { years }\end{array}$ & $\begin{array}{c}\text { Blood } \\
\text { samples }\end{array}$ & $\mathrm{x}$ & $\mathrm{x}$ & & & $\mathrm{x}$ & & & $\begin{array}{c}\text { - Recognition Memory test } \\
\text { - Digit Span } \\
\text { - Perceptual Identification } \\
\text { - Visual Attetion Vigilance }\end{array}$ & \begin{tabular}{|c|} 
Our results \\
demonstrated that \\
estrogens produced \\
a positive effect on \\
recognition \\
memory and \\
perceptual \\
identification, while \\
androgens produced \\
a negative effect. \\
Androgens also \\
produced a negative \\
effect on visual \\
attentional \\
vigilance.
\end{tabular} & \begin{tabular}{|}
- Aldults and \\
Elderly \\
- Set of tests \\
- Female \\
population \\
\\
\end{tabular} & [37] \\
\hline $\begin{array}{c}\text { Nierkerk et al } \\
\text { (2001)34 (longitudinal } \\
\text { study) }\end{array}$ & $\begin{array}{c}46 \\
(\mathrm{EM})\end{array}$ & $46 / 0$ & $\begin{array}{l}62-76 \\
\text { years }\end{array}$ & $\begin{array}{c}\text { Saliva } \\
\text { samples }\end{array}$ & $\mathrm{x}$ & & & & & & & $\begin{array}{c}\cdot \text { Word list memory } \\
\cdot \text { Object location memory } \\
\cdot \text { Choice reaction time (CRT) } \\
\cdot \text { Visual search }\end{array}$ & \begin{tabular}{|c|} 
A higher morning \\
cortisol/DHEA \\
ratio was also \\
associated with \\
lower visuo-spatial \\
memory \\
performance. But \\
no significant \\
effects of DHEA \\
treatment were \\
observed on any of \\
the trial outcomes. \\
\end{tabular} & $\begin{array}{c}- \text { Adults and } \\
\text { Elderly } \\
\cdot \text { Set of tests } \\
\cdot \text { Male } \\
\text { population } \\
\\
\end{array}$ & [34] \\
\hline
\end{tabular}




\begin{tabular}{|c|c|c|c|c|c|c|c|c|c|c|c|c|c|c|c|}
\hline Autors (Year) (Type) & $\mathbf{n}$ & $\mathbf{M} / \mathbf{F}$ & Age & \begin{tabular}{|c|}
$\begin{array}{c}\text { Body } \\
\text { fluid } \\
\text { measured }\end{array}$ \\
\end{tabular} & Memory & Attetion 1 & \begin{tabular}{|l|} 
Executive \\
Functions
\end{tabular} & $\left|\begin{array}{c}\text { Visuospatial } \\
\text { abilities and } \\
\text { psychomotor }\end{array}\right| \mathrm{F}$ & Perception & Inteligence & Global & $\begin{array}{l}\text { Neuropsychocological Assement } \\
\text { Instruments }\end{array}$ & Result & $\begin{array}{c}\text { Methodological } \\
\text { aspects }\end{array}$ & Ref \\
\hline $\begin{array}{c}\text { Aleman et al (2001)33 } \\
\text { (cross-sectional) }\end{array}$ & $\begin{array}{c}25 \\
\text { EHM }\end{array}$ & $25 / 0$ & 69,1 years & \begin{tabular}{|c|} 
Blood \\
samples
\end{tabular} & $\mathrm{x}$ & & & & & $\mathrm{x}$ & & \begin{tabular}{|c|}
$\cdot$ Information (WAIS) \\
$\cdot$ Vocabulary (WAIS) \\
$\cdot$ Benton \\
Judgement of Line Orientation \\
$\cdot$ Brus Reading Test \\
$\cdot$ Block Design (WAIS) \\
$\cdot$ Digit Symbol (WAIS) \\
$\cdot$ Concept Shifting Task \\
- Dutch version of the Rey Auditory \\
Verbal Learning Task.
\end{tabular} & 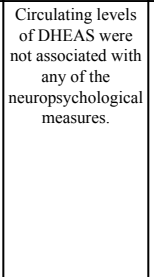 & $\begin{array}{c}\cdot \text { Elderly } \\
\cdot \text { Set of tests } \\
\text { - Male } \\
\text { population }\end{array}$ & [33] \\
\hline $\begin{array}{l}\text { Moffat et al (2000)7 } \\
\text { (longitudinal study) }\end{array}$ & $\begin{array}{l}883 \\
\text { EHM }\end{array}$ & $883 / 0$ & $\begin{array}{l}22-91 \\
\text { years }\end{array}$ & $\begin{array}{c}\text { Blood } \\
\text { samples }\end{array}$ & & & & & & & $\mathrm{x}$ & $\begin{array}{c}\text { - Benton Visual Retention test } \\
\text { (BVRT) } \\
\text { - Free and Cued Selective } \\
\text { Reminding Test } \\
\text { - Mini-Mental State Examination } \\
\text { (MMSE) } \\
\text { - Blessed Information-Memory- } \\
\text { Concentration Test } \\
\text {-2 tests of mental status assessing } \\
\text { memory, visual construction and } \\
\text { attention } \\
\text { - Semantic and phomenic word } \\
\text { fluency tests } \\
\text { - Trail-Making Tests (parts A and } \\
\text { B) } \\
\end{array}$ & \begin{tabular}{|c|} 
Decline in \\
endogenous \\
DHEAS \\
concentration is \\
independent of \\
cognitive status and \\
cognitive decline in \\
healthy aging men.
\end{tabular} & \begin{tabular}{|} 
• Young, \\
Adults and \\
Elderly \\
$\cdot$ Set of tests \\
- Male \\
population
\end{tabular} & [7] \\
\hline $\begin{array}{c}\text { Carlson and Sherwin } \\
(1999) 25 \text { (longitudinal } \\
\text { study) }\end{array}$ & $60 \mathrm{E}$ & $23 / 37$ & \begin{tabular}{|l}
72.1 and \\
73.4 years
\end{tabular} & $\begin{array}{c}\text { Blood } \\
\text { samples }\end{array}$ & & & & & & & $\mathrm{x}$ & \begin{tabular}{|c|}
$\cdot$ Weschler \\
Memory Scale (WMS) \\
$\cdot$ Paragraph \\
Recall \\
$\cdot$ Paired-Associates \\
$\cdot$ Selective Reminding Test \\
$\cdot$ WMS-Revised \\
Figural Memory \\
$\cdot$ Visual Paired-Associates \\
$\cdot$ Visual Reproduction \\
subtests \\
$\cdot$ Digit Span Forward and Backward \\
WMS-R Visual Memory Span \\
$\cdot$ Category Retrieval Test
\end{tabular} & \begin{tabular}{|c|} 
Results failed to \\
provide any \\
evidence that \\
DHEAS is \\
protective against \\
declarative memory \\
decline with aging. \\
\\
\end{tabular} & \begin{tabular}{|c|} 
Small \\
population \\
- Elderly \\
- Set of tests \\
- Male and \\
Female \\
population
\end{tabular} & [25] \\
\hline $\begin{array}{c}\text { Kalmijn et al (1998)28 } \\
\text { (longitudinal study) }\end{array}$ & $189 \mathrm{E}$ & ${ }^{*}$ & $67.3+/-5.7$ & \begin{tabular}{|c|} 
Blood \\
samples
\end{tabular} & & & & & & & $\mathrm{x}$ & $\begin{array}{l}\text { - Mini-Mental State Examination } \\
\text { (MMSE) }\end{array}$ & \begin{tabular}{|c|} 
There was an \\
inverse, but \\
nonsignificant, \\
association between \\
DHEAS and \\
cognitive \\
impairment and \\
decline. \\
\end{tabular} & \begin{tabular}{|c|} 
- Medium \\
population \\
• Elderly \\
- Screaming \\
test \\
- Male and \\
Female \\
population
\end{tabular} & [28] \\
\hline $\begin{array}{l}\text { Yaffer et al (1998)8 } \\
\text { (longitudinal study) }\end{array}$ & $\begin{array}{c}394 \\
\text { EHW }\end{array}$ & $0 / 394$ & $\begin{array}{c}65 \text { and } \\
\text { older }\end{array}$ & $\begin{array}{c}\text { Blood } \\
\text { samples }\end{array}$ & & & & & & & $\mathrm{x}$ & $\begin{array}{c}\text { - Mini-Mental State Examination } \\
\text { (MMSE) } \\
\text { - Trails B } \\
\text { - Digit Symbol }\end{array}$ & \begin{tabular}{|c|} 
DHEAS levels \\
declined with age, \\
as expected. There \\
was no consistent \\
association of \\
DHEAS quartile or \\
log DHEAS with \\
any of the four \\
outcomes, even \\
after multivariate \\
adjustment.
\end{tabular} & \begin{tabular}{|c|} 
- Large \\
population \\
- Elderly \\
- Set of tests \\
- Female \\
population \\
\end{tabular} & {$[8]$} \\
\hline $\begin{array}{l}\text { Carlson and Sherwin } \\
\text { (1998)24 (cross- } \\
\text { sectional study) }\end{array}$ & $86 \mathrm{E}$ & $41 / 55$ & $\begin{array}{c}72.19+/ 5.6 \\
\text { years }\end{array}$ & \begin{tabular}{|c|} 
Blood \\
samples
\end{tabular} & & & & & & & $\mathrm{x}$ & \begin{tabular}{|c|} 
• Paragraph \\
Recall \\
$\cdot$ Paired-Associates \\
$\cdot$ Selective Reminding Test \\
$\cdot$ Figural Memory \\
$\cdot$ Visual Paired-Associates \\
$\cdot$ Visual Reproduction \\
subtests \\
$\cdot$ Digit Span Forward and Backward \\
$\cdot$ Category Retrieval Test
\end{tabular} & \begin{tabular}{|c|} 
No significant \\
correlations were \\
found between any \\
of the hormones or \\
the DHEAS/CRT \\
ratio and scores on \\
any of the \\
neuropsychological \\
tests. \\
\end{tabular} & \begin{tabular}{|c|} 
Small \\
population \\
- Elderly \\
- Set of tests \\
- Male and \\
Female \\
population \\
\end{tabular} & [24] \\
\hline $\begin{array}{l}\text { Wolf et all (1998)35 } \\
\text { (longitudinal study) }\end{array}$ & $17 \mathrm{E}$ & $17 / 0$ & $\begin{array}{c}71.1 \pm 1.7 \\
\text { years }\end{array}$ & $\begin{array}{c}\text { Blood } \\
\text { samples }\end{array}$ & $\mathrm{x}$ & & & & & & & $\begin{array}{c}\text { - Picture memory test } \\
\text { - City map test } \\
\text { - Verbal fluency }\end{array}$ & $\begin{array}{l}\text { DHEA treatment } \\
\text { did not enhance } \\
\text { memory }\end{array}$ & \begin{tabular}{|c|} 
Small \\
population \\
- Elderly \\
- Set of tests \\
- Male \\
population \\
\end{tabular} & [35] \\
\hline $\begin{array}{l}\text { Wolf et al (1997)40 } \\
\text { (longitudinal study) }\end{array}$ & $40 \mathrm{E}$ & $25 / 15$ & \begin{tabular}{|l|}
$69,4+/-1,2$ \\
(M) 69,1 \\
$+/-1,7$ (W)
\end{tabular} & $\begin{array}{c}\text { Blood } \\
\text { samples }\end{array}$ & $\mathrm{x}$ & $\mathrm{x}$ & $\mathrm{x}$ & & & & & \begin{tabular}{|c|}
$\cdot$ Concentration \\
$\cdot$ Picture Memory test \\
$\cdot$ Stroop test \\
$\cdot$ Digit Span forward and backwards \\
$\cdot$ Number connecting \\
$\cdot$ Auditory verbal learning test
\end{tabular} & $\begin{array}{c}\text { DHEA replacement } \\
\text { had no strong } \\
\text { beneficial effect on } \\
\text { any of the measured } \\
\text { psychological or } \\
\text { cognitive } \\
\text { parameters in either } \\
\text { sex (all } P .0 .20) \\
\end{array}$ & \begin{tabular}{|c|} 
Small \\
population \\
- Elderly \\
- Set of tests \\
- Male and \\
Female \\
population
\end{tabular} & [40] \\
\hline
\end{tabular}

Legend: DP - Depressed Pacients; C - Controls; PMW - Postmenopausal women; EFD - Eldery with Functional Decline; E - Eldery; M- Men; W Women; EHW - Eldery Healthy Women; YM - Young Men; EHM - Eldery Healthy Men; P - Placebo; DT - DHEA Treatment; *unspecified. 


\section{DISCUSSION}

To discuss the relationship between DHEA, DHEA-S and cognitive function in populations of regular development, it is important to analyze all methodologic differences observed. Methodology design will be discussed in three levels: (1) type of study (with endogenous or exogenous hormones); (2) populations characteristics; (3) instruments used.

Regarding the type of study, some studies focused on endogenous levels whereas others focused on DHEA supplementation. No other review compiled studies with endogenous levels. In this review it was observed that studies that focused on endogenous DHEA-S levels showed a positive correlation with global cognition in women and men and a positive correlation with working memory, attention and verbal fluency (executive function) in women [9, 27 - 29, $33,39]$.

We speculate that the neuropsychiatric and cognitive effects of DHEA and DHEA-S are modulated by $\gamma^{-}$ aminobutyric acid-A receptor antagonistic effects, N-Methyl-D-aspartic acid and $\sigma$-receptor potentiation effects. These hormones increases regional serotonin and dopamine activity in the brain, hippocampal primed burst potentiation and cholinergic function, anti glucocorticoid activity, inhibition of production of proinflammatory factors and bioavailability of insulin-like growth factor I [17 - 20, 52, 53]. These findings can bring greater evidence for the repercussion of DHEA-S in global cognition, working memory, attention and verbal fluency verified in this review.

However, studies with DHEA replacement failed to improve such cognitive functions [35, 41, 42, 45, 47] or even worsened their performance (negatively correlated) [36, 44]. This finding corroborates other reviews about DHEA replacement. There were four previous reviews on DHEA supplementation [54 - 57]. They showed that DHEA supplementation does not affect cognition in unimpaired people. In this review, just one of the longitudinal study with DHEA supplementation showed a positive influence on memory. However, this study comprised of young male population and a $300 \mathrm{mg}$ dosage for supplementation [43], whereas other studies cited in this present review and studies cited in the previous reviews focused on elderly people using a $25 \mathrm{mg}$ or a $50 \mathrm{mg}$ dosage. This comparison highlights the necessity of using higher doses to achieve positive effects on cognition. However, the safety of this treatment is controversial and the risk of side effects may increase at higher doses [16, 57], although it is noteworthy that the side effects associated with DHEA use are described by literature as mild [6].

The second category of analyses clarifies additional data. Studies' designs were different in many points, such as age and the number of subjects. In the only study that proved the influence of DHEA supplementation on memory [43], the population comprised of young men. DHEA and DHEA-S concentrations peak at approximately 20 years-old and decay over time [4 - 6, 9 - 12, 15]; thus, young men have higher endogenous levels of these hormones before treatment. The other studies that did not demonstrate differences in global cognition after DHEA supplementation were all conducted on with elderly people. This finding also corroborates a previously study [56] which suggested that age related changes of human DHEA metabolic pathways may contribute to the relative inefficacy of DHEA replacement therapy.

In another article [10], a cross-sectional study showed no relationship between cognition and DHEA-S in both genders. Participants' ages ranged from 22 years to 91 years and this variation might have affected the outcome because of the differences in hormone levels in the young and elderly. This factor can explain why this finding contradicts other cross-sectional studies that demonstrate a positive correlation between DHEA-S and global cognition in both gender and memory in women.

An analysis of the characteristic of the sample in articles that did not show any correlation between endogenous hormone levels and global cognition included those with a mixed population (men and women) [30 - 32].

Regarding these differences observed in these studies, it is important to discuss gender differences in the effects of DHEA and its sulfate on memory, attention and executive function. Results that showed higher influences on memory, attention and executive function were all studies constituted of elderly women. Several authors explained this difference based on the dynamics of aging and metabolism in men and women: men have a higher exposure to gonadal hormones, which may have physical, mental and emotional implications [5]. DHEA, despite being the primary pro-hormone, is still present in lower levels in women [4]. In menopause, DHEA becomes the primary source of sex hormones in women; however, at this period, DHEA levels have declined by approximately $60 \%$. In postmenopausal women, these levels may become undetectable in several cases. Because no other significant source of those hormones is available after menopause, low DHEA levels are associated with the majority of medical problems observed in postmenopausal women. In men, DHEA levels reach only $40 \%$ between the ages of 65 years and 75 years, and men continue to receive a 
nearly constant supplementation of sex hormones from the testis throughout life, which can minimize the consequences of the DHEA deficit [58 - 61]. These findings call the attention for the longer exposure and higher concentrations to these hormones in men, which may explain the differences between genders in this review.

Other methodological factors that may contribute to the discrepancy are the different assessment materials. Different tests were used to evaluate memory, for example, some of them assessing just working memory [12, 39] or immediate auditory memory [5, 40,45, 46], visual memory [43], recognition memory [44]. Others used a set of tests to evaluate memory as a whole [41, 42, 47]. Maybe because of these methodological discrepancies, it was possible to observe the influence of DHEA-S just in women's working memory.

Even across studies that used the same test, results can be biased due to the sensitivity of the test. In category Global Cognition, six articles evaluated global cognitive function using the MMSE [5, 9, 11, 32, 33, 35], which is a screening test that may not detect mild manifestations of cognitive dysfunction. Screening tests are widely used but are less sensitive to mild impairment [21]. Of these studies, four [11, 30, 32, 35] did not demonstrate any correlation between DHEA-S and memory. It could have happened because the tests were not sensitive enough to memory dysfunctions.

\section{CONCLUSION}

The analysis of the studies' design clarified data and showed a positive correlation between DHEA-S and global cognition in women and men, and positive correlations with working memory, attention and verbal fluency in women only. Studies with DHEA supplementation did not improve cognitive functions or worsened the performance of such functions. The only study in which DHEA supplementation was successful was conducted among young men and with higher doses of DHEA (300 mg). The use of higher doses in elderly populations should be considered in future studies because of the age-related changes in DHEA metabolism. Therefore, before the use of DHEA supplementation for cognition in clinical practice, more studies are necessary to ensure the safety of the procedure.

\section{CONFLICT OF INTEREST}

The authors confirm that this article content has no conflict of interest.

\section{ACKNOWLEDGEMENTS}

Declared none.

\section{REFERENCES}

[1] Speroff L, Glass RH, Kase NG. Endocrinologia ginecológica clínica e infertilidade. $5^{\text {th }}$ ed. São Paulo: Manole 1995.

[2] Wajchenberg BL. Tratado de encdocrinologia clínica. São Paulo: Roca 1992.

[3] Wolkowitz OM, Rothschild AJ. Psychoneuroendocrinology: The scientific sasis of clinical practice. Arlington, Virgínia: American Psychiatric Publishing, Inc. 2003.

[4] Labrie F, Luu-The V, Labrie C, Simard J. DHEA and its transformation into androgens and estrogens in peripheral target tissues: intracrinology. Front Neuroendocrinol 2001; 22(3): 185-212. [http://dx.doi.org/10.1006/frne.2001.0216] [PMID: 11456468]

[5] Rueda Alfaro S, Serra-Prat M, Palomera E, et al. mataró aging study group. Hormonal determinants of depression and cognitive function in independently-living elders. Endocrinol Nutr 2008; 55(9): 396-401. [http://dx.doi.org/10.1016/S1575-0922(08)75076-9] [PMID: 22974452]

[6] Peixoto C, Devicari Cheda JN, Nardi AE, Veras AB, Cardoso A. The effects of dehydroepiandrosterone (DHEA) in the treatment of depression and depressive symptoms in other psychiatric and medical illnesses: a systematic review. Curr Drug Targets 2014; 15(9): 901-14. [http://dx.doi.org/10.2174/1389450115666140717111116] [PMID: 25039497]

[7] Lennartsson AK, Theorell T, Kushnir MM, Jonsdottir IH. Low levels of dehydroepiandrosterone sulfate in younger burnout patients. PLoS One 2015; 10(10): e0140054.

[http://dx.doi.org/10.1371/journal.pone.0140054] [PMID: 26441131]

[8] Ghisleni C, Bollmann S, Biason-Lauber A, et al. Effects of steroid hormones on sex differences in cerebral perfusion. PLoS One 2015; 10(9): e0135827.

[http://dx.doi.org/10.1371/journal.pone.0135827] [PMID: 26356576]

[9] Haren MT, Banks WA, Perry Iii HM, et al. Predictors of serum testosterone and DHEAS in African-American men. Int J Androl 2008; 31(1): 50-9.

[PMID: 18190426]

[10] Moffat SD, Zonderman AB, Harman SM, Blackman MR, Kawas C, Resnick SM. The relationship between longitudinal declines in 
dehydroepiandrosterone sulfate concentrations and cognitive performance in older men. Arch Intern Med 2000; 160(14): 2193-8. [http://dx.doi.org/10.1001/archinte.160.14.2193] [PMID: 10904463]

[11] Yaffe K, Ettinger B, Pressman A, et al. Neuropsychiatric function and dehydroepiandrosterone sulfate in elderly women: a prospective study. Biol Psychiatry 1998; 43(9): 694-700. [http://dx.doi.org/10.1016/S0006-3223(97)00303-X] [PMID: 9583004]

[12] Fonda SJ, Bertrand R, O’Donnell A, Longcope C, McKinlay JB. Age, hormones, and cognitive functioning among middle-aged and elderly men: cross-sectional evidence from the Massachusetts Male Aging Study. J Gerontol A Biol Sci Med Sci 2005; 60(3): 385-90. [http://dx.doi.org/10.1093/gerona/60.3.385] [PMID: 15860479]

[13] Castanho TC, Moreira PS, Portugal-Nunes C, et al. The role of sex and sex-related hormones in cognition, mood and well-being in older men and women. Biol Psychol 2014; 103: 158-66.

[http://dx.doi.org/10.1016/j.biopsycho.2014.08.015] [PMID: 25196100]

[14] Maggio M, De Vita F, Fisichella A, et al. DHEA and cognitive function in the elderly. J Steroid Biochem Mol Biol 2015; 145: 281-92. [http://dx.doi.org/10.1016/j.jsbmb.2014.03.014] [PMID: 24794824]

[15] Guyton AC, Hall JE. Tratado de Fisiologia Médica. 10 ${ }^{\text {th }}$ ed. Rio de Janeiro: Guanabara Koogan 2002.

[16] Genazzani AR, Pluchino N. DHEA therapy in postmenopausal women: the need to move forward beyond the lack of evidence. Climacteric 2010; 13(4): 314-6. [http://dx.doi.org/10.3109/13697137.2010.492496] [PMID: 20540592]

[17] Pittenger C, Duman RS. Stress, depression, and neuroplasticity: a convergence of mechanisms. Neuropsychopharmacology 2008; 33(1): 88-109. [http://dx.doi.org/10.1038/sj.npp.1301574] [PMID: 17851537]

[18] Maninger N, Wolkowitz OM, Reus VI, Epel ES, Mellon SH. Neurobiological and neuropsychiatric effects of dehydroepiandrosterone (DHEA) and DHEA sulfate (DHEAS). Front Neuroendocrinol 2009; 30(1): 65-91. [http://dx.doi.org/10.1016/j.yfrne.2008.11.002] [PMID: 19063914]

[19] Charalampopoulos I, Remboutsika E, Margioris AN, Gravanis A. Neurosteroids as modulators of neurogenesis and neuronal survival. Trends Endocrinol Metab 2008; 19(8): 300-7. [http://dx.doi.org/10.1016/j.tem.2008.07.004] [PMID: 18771935]

[20] Moser U, Wadsak W, Spindelegger C, et al. Hypothalamic serotonin-1A receptor binding measured by PET predicts the plasma level of dehydroepiandrosterone sulfate in healthy women. Neurosci Lett 2010; 476(3): 161-5. [http://dx.doi.org/10.1016/j.neulet.2010.04.020] [PMID: 20399839]

[21] Lezak MD, Howieson DB, Loring DW. Neuropsychological assessment. $4^{\text {th }}$ ed. Oxford, Oxfordshire: Oxford University Press 2004.

[22] Miotto EC, Lucia MC. Scaff M Neuropsicologia e as Interfaces com as neurociências. São Paulo: Casa do Psicólogo 2007.

[23] Fuentes D, Malloy-Diniz LF, Camargo CH, Cosenza RM. Neuropsicologia: teoria e prática. Porto Alegre, Rio Grande do Sul: Artmed 2008.

[24] Malloy-Diniz LF, Fuentes D, Mattos P, Abreu N. Avaliação Neuropsicológica. São Paulo: Artmed 2010.

[25] Moher D, Liberati A, Tetzlaff J, Altman DG. Preferred reporting items for systematic reviews and meta-analyses: the PRISMA statement. PLoS Med 2009; 6(7): e1000097. [http://dx.doi.org/10.1371/journal.pmed.1000097] [PMID: 19621072]

[26] Antunes HK, Santos RF, Cassilhas R, et al. Exercício físico e função cognitiva: uma revisão. Rev Bras Med Esporte 2006; $12(2)$ : 108-14. [http://dx.doi.org/10.1590/S1517-86922006000200011]

[27] Glei DA, Goldman N, Weinstein M, Liu IW. Dehydroepiandrosterone sulfate (DHEAS) and health: does the relationship differ by sex? Exp Gerontol 2004; 39(3): 321-31.

[http://dx.doi.org/10.1016/j.exger.2003.11.003] [PMID: 15036391]

[28] Goldman N, Glei DA. Sex differences in the relationship between DHEAS and health. Exp Gerontol 2007; $42(10): 979-87$. [http://dx.doi.org/10.1016/j.exger.2007.05.005] [PMID: 17604586]

[29] Fukai S, Akishita M, Yamada S, et al. Association of plasma sex hormone levels with functional decline in elderly men and women. Geriatr Gerontol Int 2009; 9(3): 282-9.

[http://dx.doi.org/10.1111/j.1447-0594.2009.00534.x] [PMID: 19702939]

[30] Carlson LE, Sherwin BB. Steroid hormones, memory and mood in a healthy elderly population. Psychoneuroendocrinology 1998; 23(6): 583-603. [http://dx.doi.org/10.1016/S0306-4530(98)00025-0] [PMID: 9802129]

[31] Carlson LE, Sherwin BB. Relationships among cortisol (CRT), dehydroepiandrosterone-sulfate (DHEAS), and memory in a longitudinal study of healthy elderly men and women. Neurobiol Aging 1999; 20(3): 315-24. [http://dx.doi.org/10.1016/S0197-4580(99)00052-4] [PMID: 10588579]

[32] Arai H, Takech H, Wada T, et al. Usefulness of measuring serum markers in addition to comprehensive geriatric assessment for cognitive impairment and depressive mood in the elderly. Geriatr Gerontol Int 2006; 6: 7-14. [http://dx.doi.org/10.1111/j.1447-0594.2006.00327.x] 
[33] Kedziora-Kornatowska K, Beszczyńska-Oleś R, Kornatowski T, Szadujkis-Szadurski L. The analysis of dehydroepiandrosterone sulphate concentration in elderly age women depending on coexisting disease states. Adv Med Sci 2007; 52(Suppl. 1): 126-30. [PMID: 18229649]

[34] Chua CK, Henderson VW, Dennerstein L, Ames D, Szoeke C. Dehydroepiandrosterone sulfate and cognition in midlife, post-menopausal women. Neurobiol Aging 2014; 35(7): 1654-5. [http://dx.doi.org/10.1016/j.neurobiolaging.2014.01.140] [PMID: 24612674]

[35] Kalmijn S, Launer LJ, Stolk RP, et al. A prospective study on cortisol, dehydroepiandrosterone sulfate, and cognitive function in the elderly. J Clin Endocrinol Metab 1998; 83(10): 3487-92 [http://dx.doi.org/10.1210/jcem.83.10.5164] [PMID: 9768651]

[36] Parsons TD, Kratz KM, Thompson E, Stanczyk FZ, Buckwalter JG. Dhea supplementation and cognition in postmenopausal women. Int J Neurosci 2006; 116(2): 141-55. [http://dx.doi.org/10.1080/00207450500341506] [PMID: 16393880]

[37] Luria AR. Fundamentos de Neuropsicologia. São Paulo: Ed. da Universidade Federal de São Paulo 1981.

[38] Andrade VM, dos Santos FH, Bueno OF. Neuropsicologia Hoje. São Paulo: Artes Médicas 2004.

[39] Davis SR, Shah SM, McKenzie DP, Kulkarni J, Davison SL, Bell RJ. Dehydroepiandrosterone sulfate levels are associated with more favorable cognitive function in women. J Clin Endocrinol Metab 2008; 93(3): 801-8. [http://dx.doi.org/10.1210/jc.2007-2128] [PMID: 18073302]

[40] Aleman A, de Vries WR, Koppeschaar HP, et al. Relationship between circulating levels of sex hormones and insulin-like growth factor-1 and fluid intelligence in older men. Exp Aging Res 2001; 27(3): 283-91. [http://dx.doi.org/10.1080/036107301300208718] [PMID: 11441649]

[41] van Niekerk JK, Huppert FA, Herbert J. Salivary cortisol and DHEA: association with measures of cognition and well-being in normal older men, and effects of three months of DHEA supplementation. Psychoneuroendocrinology 2001; 26(6): 591-612. [http://dx.doi.org/10.1016/S0306-4530(01)00014-2] [PMID: 11403980]

[42] Wolf OT, Naumann E, Hellhammer DH, Kirschbaum C. Effects of dehydroepiandrosterone replacement in elderly men on event-related potentials, memory, and well-being. J Gerontol A Biol Sci Med Sci 1998; 53(5): M385-90. [http://dx.doi.org/10.1093/gerona/53A.5.M385] [PMID: 9754145]

[43] Alhaj HA, Massey AE, McAllister-Williams RH. Effects of DHEA administration on episodic memory, cortisol and mood in healthy young men: a double-blind, placebo-controlled study. Psychopharmacology (Berl) 2006; 188(4): 541-51. [http://dx.doi.org/10.1007/s00213-005-0136-y] [PMID: 16231168]

[44] Hirshman E, Merritt P, Wang CC, et al. Evidence that androgenic and estrogenic metabolites contribute to the effects of dehydroepiandrosterone on cognition in postmenopausal women. Horm Behav 2004; 45(2): 144-55. [http://dx.doi.org/10.1016/j.yhbeh.2003.09.008] [PMID: 15019802]

[45] Merritt P, Stangl B, Hirshman E, Verbalis J. Administration of dehydroepiandrosterone (DHEA) increases serum levels of androgens and estrogens but does not enhance short-term memory in post-menopausal women. Brain Res 2012; 1483: 54-62. [http://dx.doi.org/10.1016/j.brainres.2012.09.015] [PMID: 22985672]

[46] Kritz-Silverstein D, von Mühlen D, Laughlin GA, Bettencourt R. Effects of dehydroepiandrosterone supplementation on cognitive function and quality of life: the DHEA and Well-Ness (DAWN) Trial. J Am Geriatr Soc 2008; 56(7): 1292-8. [http://dx.doi.org/10.1111/j.1532-5415.2008.01768.x] [PMID: 18482290]

[47] Wolf OT, Neumann O, Hellhammer DH, et al. Effects of a two-week physiological dehydroepiandrosterone substitution on cognitive performance and well-being in healthy elderly women and men. J Clin Endocrinol Metab 1997; 82(7): 2363-7. [PMID: 9215320]

[48] Azurmendi A, Braza F, Sorozabal A, et al. Cognitive abilities, androgen levels, and body mass index in 5-year-old children. Horm Behav 2005; 48(2): 187-95. [http://dx.doi.org/10.1016/j.yhbeh.2005.03.003] [PMID: 15878571]

[49] Dalgalarrondo P. Psicopatologia e semiologia dos transtornos mentais. $2^{\text {nd }}$ ed. Porto Alegre: Artmed 2008.

[50] Schelini PW. Teoria das inteligências fluida e cristalizada: início e evolução. Estud Psicol 2006; 11: 323-32.

[51] Gomes CM, Borges OR. Psychometric proprieties of visual-spatial ability tests kit. Psico-USF 2009; 14(1): 19-34. [http://dx.doi.org/10.1590/S1413-82712009000100004]

[52] Carta MG, Bhat KM, Preti A. GABAergic neuroactive steroids: a new frontier in bipolar disorders? Behav Brain Funct 2012; 19: 8-61. [http://dx.doi.org/10.1186/1744-9081-8-61]

[53] Hardoy MC, Serra M, Carta MG, Contu P, Pisu MG, Biggio G. Increased neuroactive steroid concentrations in women with bipolar disorder or major depressive disorder. J Clin Psychopharmacol 2006; 26(4): 379-84. [http://dx.doi.org/10.1097/01.jcp.0000229483.52955.ec] [PMID: 16855455]

[54] Goel RM, Cappola AR. Dehydroepiandrosterone sulfate and postmenopausal women. Curr Opin Endocrinol Diabetes Obes 2011; 18(3): $171-6$. [http://dx.doi.org/10.1097/MED.0b013e3283461818] [PMID: 21478748] 
[55] Davis SR, Panjari M, Stanczyk FZ. Clinical review: DHEA replacement for postmenopausal women. J Clin Endocrinol Metab 2011; 96(6): 1642-53.

[http://dx.doi.org/10.1210/jc.2010-2888] [PMID: 21411558]

[56] Sorwell KG, Urbanski HF. Dehydroepiandrosterone and age-related cognitive decline. Age (Dordr) 2010; $32(1)$ : 61-7. [http://dx.doi.org/10.1007/s11357-009-9113-4] [PMID: 19711196]

[57] Huppert FA, Van Niekerk JK. WITHDRAWN: Dehydroepiandrosterone (DHEA) supplementation for cognitive function. Cochrane Database Syst Rev 2006; 18(2): CD000304. [PMID: 17636627]

[58] Labrie F. DHEA, important source of sex steroids in men and even more in women. Prog Brain Res 2010; 182: 97-148. [http://dx.doi.org/10.1016/S0079-6123(10)82004-7] [PMID: 20541662]

[59] Orentreich N, Brind JL, Rizer RL, Vogelman JH. Age changes and sex differences in serum dehydroepiandrosterone sulfate concentrations throughout adulthood. J Clin Endocrinol Metab 1984; 59(3): 551-5. [http://dx.doi.org/10.1210/jcem-59-3-551] [PMID: 6235241]

[60] Heinz A, Weingartner H, George D, Hommer D, Wolkowitz OM, Linnoila M. Severity of depression in abstinent alcoholics is associated with monoamine metabolites and dehydroepiandrosterone-sulfate concentrations. Psychiatry Res 1999; 89(2): 97-106. [http://dx.doi.org/10.1016/S0165-1781(99)00099-2] [PMID: 10646828]

[61] Wolkowitz OM, Reus VI, Roberts E, et al. Dehydroepiandrosterone (DHEA) treatment of depression. Biol Psychiatry 1997; 41(3): 311-8. [http://dx.doi.org/10.1016/S0006-3223(96)00043-1] [PMID: 9024954]

(C) de Menezes et al.; Licensee Bentham Open.

This is an open access articles licensed under the terms of the Creative Commons Attribution-Non-Commercial 4.0 International Public License (CC BY-NC 4.0) (https://creativecommons.org/licenses/by-nc/4.0/legalcode), which permits unrestricted, non-commercial use, distribution and reproduction in any medium, provided that the work is properly cited. 